\title{
「町家ブーム」から見た大都市インナーエリアの地域社会変動
} 京都・西陣地区の事例から-

\section{The Machiya Boom and Neighborhood Changes in Urban Central Kyoto:} A Case Study of Nishijin

\section{金 善美 \\ Sunmee KIM}

This article aims to explore the role of the machiya boom in central Kyoto's urban regeneration through an analysis of the Nishijin area. Over the past 20-30 years, there has been an increasing interest in preserving machiya (traditional wooden townhouses) in Kyoto. Nishijin, a famed and historic weaving district, has undergone one of the most dramatic examples of neighborhood change in Japan with regard to commercial renovation of traditional townhouses.

Since the late 1990s, the machiya boom has seen multiple stages of expansion by numerous actors. Initially, it was only a grassroots movement by a few individuals, but local government and real estate developers began to champion the movement alongside the rise of machiya's social and cultural value. Under new urban policy goals, machiya, which had previously been considered obsolete, turned into a symbol of Kyoto's authentic landscape. Furthermore, the popularity of machiya encouraged reinvestment and conversion of use, stimulating both the real estate market and the tourist industry. Consequently, machiya was revived as an experiential art form compared with industrial housing production.

Although previous researchers have emphasized the contribution of the machiya boom to Kyoto's landscape preservation, this article discusses the risk of expanding destination culture as a result of machiya preservation and renovation. Strict building regulations under current urban policy may restrain gentrification from new building, but there is a limitation on how much control can be exerted over machiya commercialization regarding the loss of the culture and history that was part of everyday life in old Kyoto.

\section{1. 問題の所在}

\section{1. 国際観光都市・京都のインナーエリア}

昨今のグローバリゼーションと脱工業化社会への移行の中で大都市インナーエリアの地 域社会が経験する変貌、あるいは再生の過程は、後期資本主義の発展と密接に連動しなが ら再編されていく都市空間を映し出すものとして注目を集めてきた。中でも、欧米諸国に 
比べて工業社会の名残を相対的に強く留めながら再都市化が進む日本都市のインナーエリ アについては、東京を中心にその展開を解明した研究成果の蓄積がある [布施 1990 ; 高橋 編 1992]。そこからは、産業の衰退や地域コミュニティの解体、再開発に伴う新・旧住民 の共存なぼ、工業社会一脱工業化社会の間の接続・調和の問題が指摘されてきた。

京都は世界的な観光都市であると同時に、国内有数の工業都市でもある ${ }^{1)}$ 。島津製作所 や京セラ、ワコール、オムロンといつた近代的工業の企業群が京都で生まれており、その 土台には西陣織や京友禅、清水焼など、日本文化を代表する数々の伝統産業の存在があ る。とりわけ、これらの産業の多くは「洛中」と呼ばれる平安京の中心部に立地し、職住 一体型の独特な地域社会を作り上げてきた。様々な伝統産業が地場産業として明確な存在 感を持ち、住民の生活様式や地域文化のあり方、さらには町並みまでを総合的に規定して きたところに、京都のインナーエリアの最大の特徵がある。

もちろん、製造業全般の衰退という時代の流れから、京都も決して例外だつたわけでは ない。産業構造の転換や低成長時代の到来、消費者ニーズの変化などにより、伝統産業の 小規模事業所が多数を占める京都の製造業は大きく縮小してきた。しかしながら、京都の インナーエリアは単に衰退していくのではなく、国際観光都市化の影響の下でより複雑な 変貌を遂げているように見える。京都は1994年の国際連合教育科学文化機関 (UNESCO) の世界文化遺産登録 ${ }^{2}$ をきつかけに世界有数の観光都市としての地位を獲得し、近年では 観光客数・観光消費額ともに最高記録を繰り返し更新している3）。日、京都のインナー エリアは観光の舞台として絶えず都市としての歴史性・文脈性が意識される場所となって おり、このことは伝統産業の立地に基づく地域社会が変貌しつつも存続している一要因で ある。

本稿の対象地である京都市上京区・西陣地区は、こうした京都のインナーエリアの状況 を代表する場所である。西陣織の産地で知られる西陣地区では、1990年代後半より市民が 始めた町家再生の試みが「町家ブーム」4) という社会現象にまで発展し、思わぬ変化を引 き起こしてきた。老朽家屋に過ぎなかった西陣地区の町家は「町家ブーム」を経て「京都 らしい」歴史的景観の象徵に生まれ変わり、新たな社会的・経済的・文化的価值を生み出 すものとして、政策による保護や投資家らの投資の対象と化した。近年、古い町並みの保 全・活用によって地域の再活性化を目指す取り組みは珍しくないが、観光産業の影響下で 工業の生産空間の商業的転用が爆発的な勢いを持って広がった点や、市民による試みが結 果的に都市計画や不動産市場を突き動かすところまで発展した点に、本事例の特殊性があ る。

\section{2. 先行研究と本研究の位置づけ、研究方法}

西陣地区における「町家ブーム」の分析に際して、本稿では先行研究を二つの流れに分 けて考えてみたい。一つ目の流れは、西陣の産業と地域社会の特殊性に関する研究であ 
る。西陣織という伝統産業の存在感ゆえに、西陣については「町家ブーム」以前から経済 学や地理学、社会学などの分野を中心に活発な調査研究がなされてきた。そこには、典型 的な労働集約的産業である西陣織業の産業構造の前近代性と零細性を日本経済の二重構造 が生み出した矛盾の一つとしてとらえ、現代資本主義の発展に伴う産業と地域社会の変容 を解明するという共通の関心があった [黒松 1965 ; 松井 1979 ; 谷口他編 1993 ; 渡邊 1997]。

二つ目の流れは、1990年代後半以降の町家再生の動きに着目した一連の研究である。先 にこの現象に目を向けたのは建築・都市計画分野で、研究者らの多くは京都市による町家 の実地調査や景観まちづくりの取り組みを追いながら、西陣地区における町家再生を「京 都らしい」景観の保全に向けた動きとして位置づけた [青山 2002 ; 片方 2007 ; 宗田 2009]。 一方、「町家ブーム」の拡大とともに登場した社会学や人類学、歴史学分野の研究は、同 様に町家再生を「京都らしさ」の保全に関わる問題として把握しながらも、その背景にあ る社会的・経済的要因をより多角的に問うことで、総合的な社会現象としての「町家ブー ム」を論じてきた [Brumann 2012 ; 京都新聞社編 1995 ; 逢・中村 2008 ; 野田 2006]。

本稿は、これら二つの研究の流れの間に存在する断絶に着目する。「町家ブーム」に関 する既存研究の多くはそれを景観保全という枠組みから把握し、すでにその特殊性が指摘 されてきた西陣の地域社会の変容と関連づけてとらえる視点は必ずしも十分ではなかっ た。西陣の町家再生はどちらかというと京都全体の社会経済的変容という文脈の中で論じ られるか、あるいは、地域社会の特殊性との関連に注目した研究でも、建造環境の変化 [片方 2007 ; 花岡他 2009] など特定の側面の分析に留まってきた。しかしながら、産業 の衰退の中で登場した「町家ブーム」をインナーエリアの歴史的文脈の中で位置づけ、そ の意味を説明するためには、町家を生み出した産業や地域社会の変容までを含めた考察が 欠かせない。

従つて本稿では、市民による草の根的な試みが複数のアクターの介入の中で「町家ブー ム」に発展していく一連の過程を時系列的に整理すると同時に、それと連動する地域社会 の展開を産業・人口構造や土地利用の変化、関係者へのインタビューなどから分析してい く。地域社会の社会的・経済的・文化的変容を総合的にとらえることで、上述した先行研 究の断絶を克服し、単なる景観保全の枠組みを超えたインナーエリアの地域社会変動とい う観点から「町家ブーム」の展開を検討することが可能となる。景観保全を訴える既存の 市民運動 ${ }^{5)}$ 、あるいはジェントリフィケーション的都市開発 ${ }^{6)}$ という枠組みだけでは説明 しきれない西陣地区の事例を解明することで、京都という都市ならではの展開の特殊性を 明らかにし、転換期にある今日の大都市インナーエリアに対する示唆を与えることが本稿 の目的である。

本稿で用いた主な研究方法は、資料分析とインタビュー調査である。資料分析の対象と なったのは行政文献や国勢調査などの統計データ、「町家ブーム」についての新聞・雑誌 
の記事、インターネット上のブログや町家紹介サイトなどである。インタビューは 2016 年 6 月から 10 月の間に実施し、市民グループのメンバーや個人、住民有志、行政関係者、 西陣織関係者、自営業者、都市計画とまちづくりの専門家ら 12 人を対象に行つた。

続く第 2 節では、西陣の地域社会の特徵を産業との関連の中で論じ、産業の衰退が始 まった 1990 年代以降の変化に触れる。その上で、第 3 節では、市民による草の根的な活動 が「町家ブーム」にまで発展していつた経緯を、社会情勢の変化や様々なアクターの働き から解明する。第4節では、「町家ブーム」を前後にした地域社会変動を国勢調査のデー タやインタビューなどから分析し、地域社会の社会的・文化的変容の過程としての「町家 ブーム」を指摘する。結論では本稿の内容をまとめ、本研究の意義と課題について触れる。

\section{2. 西陣地区の概要と地域社会の特徵}

西陣織発祥の地として広く知られてはいるものの、「西陣」という行政区域が実在する わけではなく、「西陣」の地理的範囲を巡っては諸説が存在する。従って本稿では、経済 史学者の本庄栄治郎 [1930］による定義を参照し、西陣地区を「京都市上京区・大宮通り 今出川付近を中心に広がる西陣織関連企業の集積地」とする。具体的には、桃薗・小川・ 聚楽・正親・嘉楽・乾隆・西陣の 7 つの国勢統計区から構成される範囲を指す（図 1 ）。こ れは「西陣」の定義としては比較的狭義のもので、産地問屋や大手機業など、産業構造の 上部アクターが立地する中心地とその周辺地域に当たる。

では、西陣はどのような特徽を持つ場所なのか。この問いに答えるためには、産業と地 域社会を関連づけてとらえる必要がある。西陣の地域社会構造は、西陣織の生産に関わる 多数の零細事業者からなる社会的分業体制に基づく。高級呉服としてデザイン性・芸術性

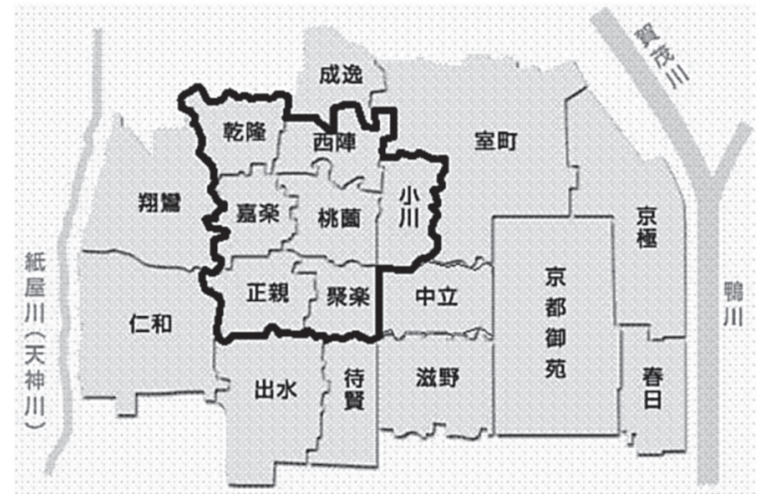

図 1 西陣地区の範囲

注：「学区案内トップページ」上京区役所ホームページ (http://www.city.kyoto.lg.jp/kamigyo/page/0000029004.html) をもとに筆者作成。 
が重視される西陣織は生産工程別に異なる職人が関わり、細密に分けられた分業体制が工 芸品としての質の高さを生み出してきた。様々な零細事業者らに仕事を配分し、生産過程 全般を管理するのは織屋（おりや）と呼ばれるメーカーで、西陣織業は織屋や産地問屋を 頂点にしてその下に多数の零細事業者が存在する階層構造を持つ。

社会的分業体制の下、住民の多くは職住一体型のライフスタイルを持ち、とりわけ産業 構造の下部に存在する多数の織手 (おりて) たちは長時間労働の家内生産に従事するのが 一般的であった。男性労働者からなる徒弟制度に基づいていた生産体制は20世紀以降、 西洋技術の導入による機械化がなされたことで、女性や子供までを労働力に含む家内工業 としての性格を強めていく。このような生産システムは賃機（ちんばた）と呼ばれ、織手 たちは織屋から糸などの材料を受け取り、注文に従って自宅の織機で商品を作って納品 し、出来高払いの収入を得た [渡邊 1997]。彼・彼女らは自営業者であると同時に雇用者 として西陣織の生産を支えてきたが、そうした位置づけの曖昧さは労働者としての権利確 保を難しくさせ、織手たちは長らく劣悪な雇用環境に留まってきた [Hareven 2002]。

産業構造の特徵は、建造環境と住宅の所有形態にまで影響を及ぼした。西洋技術の導入 以降、西陣では屋内に織機を置くために工房部分が広く、台所は狭い構造を持つ「織屋建 て」の町家が大量に建設されていく。これは京都の都心部でも中京区・下京区のものとは 異なる特徵を持つ類型の町家で、西陣織の家内生産に最適化された建造様式であつた。大 手の織屋は自社付近にこのような町家を多数確保し、それを格安の借家として織手などに 提供することで関連企業が集積する環境を作った [宗田 2009]。従って多くの零細事業者 にとつて仕事と住居は直結しており、このことは後に西陣織業の衰退の中で空き家状態の まま放置された町家が大量に発生する原因となった。

しかしながら、このような地域社会の特徽は、1990年代以降、急速に失われてきた。 2015 年現在、西陣織業の企業数は 321 社、従業者数は 2,674 人で、生産ピーク時であった 1975 年に比べるとそれぞれ約 $28 \%$ (企業数)、12\%（従業者数）水準まで減少した。また、 2015 年の総出荷金額も、ピーク時であった 1990 年の $12 \%$ 水準である 334 億円に留まって いる [第21次西陣機業調査委員会 2016]。衰退の背景としては、消費者の「きもの離れ」 による需要減少や、海外からの輸入製品の増加による消費者層の離脱などがあげられる [芳野 2011]。織屋の多くは生産機能を海外や郊外に移転させ、人件費を削減することで 危機に対応したが、それは長期的には産地基盤を弱体化させ、職住一体の地域社会の解体 を招いた。さらに、バブル期以降の地価高騰の中、西陣織の生産に見切りをつけ、不動産 業に進出する織屋も続出した。その結果、地場産業としての西陣織は徐々に地域社会から 分離し、町家は次々と新築の建売住宅や共同住宅、駐車場などに変わつた [花岡他 2009 ; 藤塚 1992]。一方、2000年代以降の「町家ブーム」が「町家バブル」 ${ }^{7)}$ と呼ばれる状況に まで発展する中、残っている町家の中では西陣織の生産とは無関係な商業的空間も増えて きた。 


\section{3.「町家ブーム」の展開と拡大}

\section{1. 市民による町家再生の試み}

「町家ブーム」の最初のきつかけを作ったのは、バブル経済の崩壊後、空き家状態で放 置されていた町家に興味を持ち、興味本位で改修を始めた複数の市民である。中でも、小 さな市民グループ「P」の活動はもつとも有名な事例で、もとより友人関係であった Aさ ん・Bさんが中心メンバーとなり、町家に住みたいアーティストや学生を大家に紹介する 活動や、町家を活用した様々な文化イベントなどを始めた。こうした取り組みがメディア から大きく注目される中、「P」は数々の助成金を獲得し、「アーティストの町」として西 陣地区の名前を市民社会に広めたが、その活動は 2000 年代中盤をもって終了している。

その頃は空き家だらけで、僕はそこを改装して何かしたいと思って、友達のBさん にも声をかけて。それを何かカッコいいと思ってくれたのか、「職住一体」という キャッチフレーズで新聞に載つた。そこから町家に関する問い合わせの電話がいきな り 60 件ぐらいかかってきて、急にニーズが出てきた。そのうち電話での対応も大変 になって、説明会をやりました。その時に、「会の名前は?」と聞かれたので、僕ら は世話を焼くつもりもそんなになかつたけど、まあ、「○○の会」という名前を使つた。

（中略）2003年ぐらいから不動産業界が空き町家の有効活用に乗り出してきた。彼 らは僕たちと違って商売ですから、空き家のオーナーにどんどん声をかけていく。だ から僕らのところに大家さんから物件が回って来なくなった。まあ、僕らはもともと 「飽きたらやめる」というスタンスだつたので、そこで僕らの役目は果たしたかな、と番。

$\lceil\mathrm{P}\rfloor$ とぼ同時期において独自に活動を始めた Cさんもまた、西陣における町家再生 の動きを全国的に知らせた存在である。京都に生まれ、町家を自らの「原風景」と語るC さんは解体予定であった西陣地区の町家を買い取り、Cさん自身が関わる市民活動の集会 や歴史・文化に関連する様々なイベントの貸し会場として活用してきた。Cさんの活動は 地元メディアを中心に知られはじめ、国際交流事業で日本を訪れる外国の企業・団体の日 本文化体験の場として使われることも増えていつた。

自分の原体験は町家しかなかったから、ビルなどなかったから。それで「町家って こんなに早く解体されていくのかな」という疑問もちょつとあったりして。まあ、と りあえず町家は景観として大事やから残すことが必要やな、という感じで、最終的に は私が買い取って。（中略）（行政や他のまちづくり組織とは）交流はしてない。こっ ちはそんなに交流して組織的な活動をやる㗇はない。僕が興味あったのは、自己実 現。行政とはいい加減なもんで、知事や市長が変われば方針が変わる。だからいろん 
なまちづくり組織なども含めて、付き合うのはいいけど、距離は確実においてる99。

以上の二つの事例が示すように、初期の町家再生に関わった人々は、必ずしもまちづく りや市民活動を目指したわけではなかった。そこにあったのは個々人の自由で気ままな興 味関心で、だからこそ「町家ブーム」以降、「P」はやがて活動の終了を選んだのであ り、Cさんは行政や他のまちづくり組織と意識的に距離を置いてきた。これらはよく組織 化された市民運動というょりは、あくまで個人をべースにした草の根的な試みに近かった のである。

このように自由な活動の展開は、町家再生が急速に「ブーム」になっていった時、これ らのアクターがそうした展開に対してさほど統制力を持たないことを意味するものでも あった。西陣ではこれらの個人の活動が継続的に展開され、求心力を持つ運動にまで発展 するより先に、「町家ブーム」が勢いを増していった。「自分らが何をやろうとしているの かを、あまり理解してないままでやってきたんだな、というのもこの『P』の活動で分 かった」というBさんの語り ${ }^{10)}$ のように、「町家ブーム」の主導権が他のアクターに移つ て行き、幾分のステージを経ながら拡大していく中で、初期の町家再生に関わった人々は 自らがやってきた活動の意味を事後的に認識することになる。

\section{2. 歴史的景観の保全に対する認識の変化}

では、個人の趣味として始まった町家再生の試みはなぜメディアの注目を集め、全国的 に認知されていったのか。次に、社会における認識の変化という側面から「町家ブーム」 の拡大を考察してみたい。

戦後の高度経済成長は、物質的な豊かさと同時に無分別な開発による病弊、すなわち公 害問題や環境破壊、コミュニティの解体といった問題を生み出した。このような状況は反 動として自然環境や景観の保全に関する人々の関心を高め、1970年代以降、全国各地で開 発反対の住民運動が活発化する。運動は鎌倉や奈良、有松、倉敷など、古い町並夕が残る 歴史・観光都市を中心に広がり、歴史的景観の保全がまちづくりの新たなテーマとなって いった。

また、同時期は欧米諸国を中心に都市計画のパラダイム転換が起きていた頃でもあった。 合理主義を信奉し、規格化・標準化を追求する近代都市計画への批判が高まり、魅力にか けた均質空間になってしまった都市に対して多様性や地域コミュニティといった価値を取 り戻そうとする動きが広まったのである。その潮流はやがて日本社会にも到達し、理論と 実践の両面において歴史的景観の保全を根拠づけていく[饗庭他 2008]。各地の地方自治 体では景観保全に向けた条例が制定され、1975年には文化財保護法の改正によって「重要 伝統的建造物群保存地区」の選定が始まるなど、国レベルの制度も整備されていった。

このような流れの中で、歴史的景観の保全を通じた活性化を図る「保存的開発」の方向 
性が示されるようになる [木原 1982]。歴史的景観を地域資源として活用し、観光を通じ て利益を得るという発想は多くの地方都市にとって魅力的な戦略として受け入れられ、と りわけ京都においては、町家の町並みが「京都らしい」歴史的景観の格好の象徴となつて いく。都心部に残る町家の多くは個別的には文化財として高い価值を持つわけではなかつ たが、だからこそ京都の「町衆」の文化や暮らしを物語るものとなつた。2004年には国土 交通省が『町家等の再生・活用ガイドライン』を策定し、都市再生や地域活性化のための 有効な方策として町家の活用を位置づけた。

ライフスタイルの変化もまた、町家の保全・活用への関心を高めた一要因である。都心 回帰の中、町家での暮らしは若年層を中心に新しく洗練された職住近接のライフスタイル として注目されていく。その居住空間としての長い歴史は孤立しがちな現代人に「幻想の 実家」という感覚を提供し、町家は物語性を楽しむことができる空間として認識されるよ うになつた [逢・中村 2008]。それまで単なる老朽家屋と見なされていた町家に関する社 会の認識は大きく変化し、実際の居住・生活経験の有無に関係なく、幅広い層の「町家 ファン」が生み出されていった。

\section{3. 京都市の景観政策}

このような認識の変化は、京都市のまちづくりにもそのまま反映されてきた。京都では 1980 年代初頭から地価高騰により不動産投資が集中し、マンション紛争が頻発した。高層 マンションやホテルの建設に対する反対運動は住民運動が組織化されていく基盤となり、 町家の保全と再生に取り組む市民団体も次々と結成されていつた ${ }^{11)}$ 。とりわけ、京都夕 ワーの建設をめぐる議論から始まつた景観論争の連続的な展開は歴史的景観の保全を地方 政治における主要な論点にさせ、幅広い市民がこの問題に関心を持つきつかけとなつた。

住民運動と連動する形で、京都市の景観政策にも変化が現れた。1990年年代に入ると都 市計画においても景観保全が意識されはじめ、町家は政策による管理や保護の対象となつ ていく。景観論争が続く中、1993年に策定された『新京都市基本計画』では初のゾーニン グが導入され、町家が多く残る都心部は「調和を基調とする都市再生地域」に指定された。 2003 年には「京都市都心部の新しい建築ルール」が施行され、都心部の建物に対する高 さ・容積率の制限が明文化される。市政や研究者、市民社会が協力する中で町家の実地調 査も進み、「京都市景観・まちづくりセンター」の設立 (1997) や『京町家再生プラン』 （2000）の策定など、2000年代以降、町家の保全・活用に向けた制度も幅広く整備された。

とりわけ、京都市の景観政策の歴史に一線を画したのは、2007年に策定された新景観政 策である ${ }^{12)}$ 。その最大の特徵は町家の町並みと調和する景観の設計・管理という視点が都 市計画に全面的に導入された点で、一定の限界や課題があるとはいえ13)、これは住民運動 が成し遂げた成果と言える。新景観政策を基本方針とする過去 10 年間の都市計画・まち づくりの施策の中で、西陣は町家の町並みを残す歴史的市街地として、ヒューマンスケー 
ルの都市空間を維持するための規制や措置の対象であり続けてきた。そこから、行政が 「町家ブーム」の到来を手助けしたと見なすことができる。

\section{4. 不動産市場と観光産業の動向}

このように、「町家ブーム」は当初の草の根的な動きを超えた社会現象に拡大し、町家 の保全は地方自治体による政策目標としての性格を持ち合わせていく。それは同時に、町 家が市場における「商品」と化する過程でもあった。複数のインタビュー対象者による と、西陣の町家が不動産取引の対象となったのは 2000 年代中盤だと思われる。町家に対 する認識の変化は経済的価值の上昇につながり、町家の賃料・売買価格が上昇する中 ${ }^{14)}$ 、 町家物件を専門的に手掛ける不動産屋や工務店も次々と登場した。

ここ 10 年ぐらいじゃないかな。やっぱり流行り出してから、どこもかしこもやる ようになって。(中略）時々、広告で改修された町家が賃貸に出てたりします。「お店 に使えますよ」という状態にして賃貸に出す。西陣は「織屋建て」つて言って都心部 の町家に比べて大きい空間があるので、レストランとかカフェをやろうと思ったら けっこうやりやすい形ではある ${ }^{15)}$ 。

さらに、「町家ブーム」はすでに存在する町家の保全・活用のみならず、新しく建つ住 宅のデザインやセールスのあり方にまで影響を及ぼしている。たとえば、町家の改修を手 掛ける京都の不動産会社である八清（はちせ）が2016年に竣工した新築賃貸住宅「急びす 小路」は、空には格子を設置し、建物の入り口に石畳の路地を整備するなど、外見の「町 家風」演出にこだわった物件である。また、大手建設会社の大和八ウスも、「京町家の雅 な佇まいを表現した」和風賃貸住宅である「セジュールウィット 京和風」を全国各地に 販売している。「町家風」という言葉は現代的な利便性を備えながらも建物の内外におい て和風の演出を採り入れた建築様式を表す一般的修辞として、徐々に定着しつつある。

町家の価值の上昇は、観光産業においても明確に確認される。町家にフォーカスを合わ せた京都のガイドブックが次々と出版され、その中で町家を改修したカフェやレストラ ン、物販店などは「昔ながらの色あせない風情に現代のエッセンスを加えた」16) といった 表現で紹介される。町家再生の主要アクターはアーティストなどの個人から資本に移り、 生産・居住空間としての町家は次々と商業的空間に転用されてきた。その人気は世界各国 からの観光客の間で広がり、近年ではとりわけ地域外の資本によるホテルやゲストハウ ス、一棟貸しの別荘なぞ、宿泊施設への転用が目立つ。これは町家が象徵する「京都らし さ」の諸要素を多方面にわたってじっくり体験したい観光客の要求と、飲食・物販業に比 べてより高い客単価が見込まれる宿泊施設への転用を好む経営者側の計算が一致した結果 と考えられる。 


\section{4.「町家ブーム」と西陣地区の地域社会変動}

\section{1. 住宅地化と居住者層の変化}

では、「町家ブーム」が拡大してきた過去 20 年余りの間、西陣の地域社会はどのような 変貌を遂げたのだろうか。この問いは、すでに地理学分野の研究によって部分的に解明さ れてきた。たとえば、李・吉田 [2013] は 1990 年から 2010 年までの 20 年間の西陣の繊維 産業集積の変化に関する GIS 分析を行い、全体の土地利用変化の $48 \%$ が工業から他の用途 への転換であることを明らかにした。工業・商業の土地利用に対する需要が急減し、住居 用の土地利用への需要は飛躍的に増加する中、 $300 \mathrm{~m}^{2}$ 以上の敷地を持つ織屋はほとんどな くなり、現在、地域の構造的特性を支えているのは小規模の零細事業者である ${ }^{17)}$ 。

住宅地化の傾向は、1990年から 2015 年までの国勢調査のデー夕（国勢統計区別）からも 確認できる。1995年より減少から増加に転じた西陣地区の人口は 2015 年現在、 29,000 人 に達しており、1990年の 24,984 人から約 $16.1 \%$ 増加した。同時期の上京区と京都市全体に おける人口増減率がそれぞれ約－ $5.2 \% 、 0.9 \%$ に留まっているのに比べると、西陣地区の 人口増加は明らかである。さらに、同一コーホートの人口を 1995 年と 2015 年で比較する と、とりわけ (2015年時点で) 20 代後半から 30 代前半の若年層や、40代後半から 60 代の 転入が、この間の人口増加を後押ししてきたことが分かる（表 1 )。

では、現在の西陣に住んでいるのはどのような層の人々だろうか。職業大分類別就業者 数の推移を見ると、専門技術職とサービス職の割合が増加傾向にあるのに対して、生産労 務職の割合は過去 25 年の間にほぼ半減している (表 2 )。また、従業上の地位別に見ると、 雇用者の割合が 1990 年の $71.6 \%$ から 2015 年の $84.0 \%$ ま増加しているのに対して、自営 業主の割合は $17.5 \%$ か $11.9 \%$ 、家族従業者の割合は $10.8 \%$ から $4.2 \%$ ま゙減少した。以 上からは、ホワイトカラー層の新住民の増加が製造業従事者の減少による空白をある程度 埋めてきたことが推測できる。

地区内の居住空間にも変化があった。住宅の建て方別の世帯構成を比較すると、1990年

表 1 西陣地区における人口のコーホート比較（1995-2005-2015）

\begin{tabular}{rcccccccc}
\hline & $0-4$ 歳 & $5-9$ 歳 & $10-14$ 歳 & 15-19歳 & $20-24$ 歳 & $25-29$ 歳 & 30-34歳 & 35-39歳 \\
\hline 2015 & 817 & 895 & 970 & 1,724 & 3,226 & 1,685 & 1,400 & 1,622 \\
2005 & & & 842 & 830 & 854 & 1,464 & 3,283 & 2,066 \\
1995 & & & & & 777 & 839 & 918 & 1,769 \\
\hline & $45-49$ 歳 & $50-54$ 歳 & $55-59$ 歳 & $60-64$ 歳 & $65-69$ 歳 & $70-74$ 歳 & $75-79$ 歳 & 80 歳- \\
\hline 2015 & 1,701 & 1,530 & 1,354 & 1,311 & 1,775 & 1,388 & 1,303 & 2,261 \\
2005 & 1,552 & 1,430 & 1,292 & 1,254 & 1,768 & 1,468 & 1,451 & 4,181 \\
1995 & 1,728 & 1,418 & 1,245 & 1,225 & 1,718 & 1,524 & 1,483 & 6,144 \\
\hline
\end{tabular}

注 1 ）：各年国勢調査より作成。 
表 2 西陣地区における職業大分類別就業者数の構成比（1990-2015）

\begin{tabular}{cccccccc}
\hline & 総数 & 専門技術 & 管理 & 事務 & 販売 & サービス & 生産労務 \\
\hline 1990 & 13,373 & $11.70 \%$ & $5.10 \%$ & $18.00 \%$ & $19.60 \%$ & $9.90 \%$ & $31.20 \%$ \\
1995 & 12,654 & $12.90 \%$ & $4.80 \%$ & $18.90 \%$ & $20.50 \%$ & $11.60 \%$ & $27.60 \%$ \\
2000 & 12,235 & $14.70 \%$ & $3.10 \%$ & $19.40 \%$ & $20.00 \%$ & $12.00 \%$ & $24.30 \%$ \\
2005 & 12,096 & $16.20 \%$ & $2.40 \%$ & $21.40 \%$ & $18.00 \%$ & $13.50 \%$ & $22.50 \%$ \\
2010 & 12,568 & $17.00 \%$ & $2.60 \%$ & $18.10 \%$ & $15.70 \%$ & $15.60 \%$ & $17.90 \%$ \\
2015 & 12,845 & $18.90 \%$ & $2.90 \%$ & $18.80 \%$ & $14.60 \%$ & $15.40 \%$ & $16.70 \%$ \\
\hline
\end{tabular}

注 1 ）：各年国勢調査より作成。

注 2 ）：調査年度によって職業大分類がやや異なるため、元のデータを一部加工した。具体的には、2010年度 以降の調査における「生産工程従事者」「建設・採掘従事者」「運搬・清掃・包装等従事者」の合計を 「生産労務職」として合算した。

には全体の約 $53.2 \%$ 占めていた一戸建て・長屋建ての割合は 2015 年の $31.9 \%$ ま減少し た一方、共同住宅の割合は 1990 年の $45.6 \%$ から 2015 年の $68.0 \%$ まで増加した。とりわ け、共同住宅の中でも 6 階以上の高さを持つ建物が占める割合は 1990 年には $40.7 \%$ あっ たが、2015年になると $49.0 \%$ ま゙増加した。土地利用の用途変化が進む中、中高層マン ションを中心に共同住宅が増えていることは明らかである。産業構造の転換は、町並みに も反映されつつあるのだ。

実際、現在の町を歩き回ると、築年数の古い町家が解体され、マンションや建売住宅、 駐車場に変わっていく光景を目にすることは珍しくない。長年、京都市内で事務所を運営 し、不動産の相続問題などに詳しい司法専門家のFさんは、西陣の変化を次のように説明 する。

京都の場合はビジネスと家族がずっと一致していて、そういう部分（家業の継承に 伴う建物の継承) がしつかりしていた。住居と職場が一体（の建物）だつたので、仕 事の跡取りが建物も継いでいつた。だから老舗の中ではまだまだ町家が残つていると ころはある。ところが伝統産業がどんどんダメになって、廃業したり、子供はサラ リーマンになって地域からも離れていったりする。昔は、そうなったら不動産の権利 もある程度は地域に置いていかなければいけない、という発想があった。でも今は権 利者である相続人がごこに行こうが全部持っていく。だから売却してお金にして、そ の際には一円でも効率のいい使い方をする買い主に売る。その結果、マンションが乱 立する ${ }^{18)}$ 。

西陣地区は 1974 年より「西陣特別工業地区」に指定され、産業立地を意識した都市計 画の保護を受けてきたが、とはいえ、そうした政策方針は市場の動きに勝てるものではな かった。西陣織業の生産空間であった土地が次々と宅地開発の対象となっていく中で、都 
市計画が想定していた住工商の望ましい混合状態は徐々に住宅地に傾いてきた。人口の都 心回帰の下、西陣では西陣織業の衰退に取って代わる形で土地利用や居住者層の変化が進 み、そうした土台の上で「町家ブーム」が徐々に拡大していったと言える。

\section{2. 歴史的景観の保全に触発された「目的地文化」の拡散}

従って、「町家ブーム」はそれ自体が単独で西陣地区に著しい変化をもたらしたという よりは、脱工業化の中ですでに進行中であった地域社会変動をさらに加速させる役割を果 たした。と同時に、それは先述した産業や人口構造、土地利用の変化を追うだけでは説明 できない、社会的・文化的な変容の過程としての性格を持っていた。

「町家ブーム」が生夕出した最大の変化は、言うまでもなく町家の市場価値の上昇であ る。それは詳しくは町家への再投資と用途の転用によって特徵づけられる。一時期はその 使命を終えたように見えた町家は、「町家ブーム」を経て新たな価值を獲得し、生産・居 住の空間から消費・体験の空間に生まれ変わつた。その過程は必然的に資本の再投資を伴 い、町家はいつの間にか京都の歴史と文化を象徴する公共財的性格を持つだけでなく、観 光産業と不動産業における魅力的な商品として新たな市場を切り拓いてきた。

Zukin $[2010=2013]$ は、近年のインナーエリアにおいてミドルクラスの流入と建物の再 利用といつた動きが徐々に地区イメージを変え、結果的に新たな消費と経験の目的地とし て人々を惹きつけていると指摘しながら、この現象を「目的地文化 (destination culture)」 と呼んだ。彼女に従うならば、西陣地区では「町家ブーム」によって新たな地域社会変動 が始まり、そのことが西陣織業の復活でも、住宅地化でもない再活性化の可能性を生み出 してきたと言える。西陣織の生産は縮小の一途を辿っているが、その生産空間としての町 家は「目的地文化」の対象となることで再び存在価值を得たのである。

一方、町家をリノベーションしたカフェやレストラン、ゲストハウスなどの増加とそれ らが生み出す人の流れは、「京都らしい」歴史的景観の保全をめぐるこれまでの議論に新 たな問いを投げかけている。Brumann [2012］によると、町家の用途転用はますます商業 的利用が主流となつてきており、町家が本来持つ暮らしの機能は徐々に縮小する傾向にあ る。町家の保全・再生に対する関心は主に外見に限られ、その中身である暮らしへの関心 は観光産業における追体験の領域に限定される。このような近年の状況を、先述した市民 グループ「P」のメンバーである Bさんは次のように評価する。

そもそもはコミュニティの再構築のツールとして町家が使われていたのが、ビジネ スに変わっちゃつた。(中略) ブームになっていいこともたくさんあるけど、当然な がら悪いこともものすごくある。その繰り返し。ただ、最終的には、安いものが見直 しされちゃって、高くなってしまった。町家はそもそも家賃で食べるための建物じゃ なかつたのに、ここ 20 年間で 200 年、300年でずっと安定して続いていた出来事を 
ひっくり返してしまった。だからそれは最大の失敗、とは言わないけど、方向の変化 だよね ${ }^{19) 。}$

興味深いのは、こうした「町家ブーム」以降の新たな展開において、民間の資本だけで はなく、行政もまた一定の役割を果たしてきたという点だ。前節で触れたように、京都市 の景観政策は 1990 年代以降、歴史的景観を積極的に保全していく方向に転じ、全国でもっ とも厳しいと言われるほどの景観規制がなされてきた。しかしながら、それは一方でイン ナーエリアにおける地域社会変動の方向性をより多角化させる方向に働いた。新景観政策 による建物の高さ・容積率の規制強化は確かに宅地開発の在り方に対して一定の抑制効果 を持つたが、歴史的景観が持つ価値を強調し、規制・管理の対象を主に町の「見た目」に 設定した点では、むしろ町家の市場価値の上昇と商業的転用を後押しする側面があった。 その結果、今日の西陣地区で見られる地域社会変動は、景観規制による制限付きの住宅地 化と、歴史的景観の保全に触発された「目的地文化」の拡散の同時進行で説明できる。

そしていずれの展開においても、その核心的な担い手となったのは地主層、とりわけ西 陣織業の上部アクターである織屋であった。彼・彼女らは産業と地域社会をリードしてき た存在であると同時に、1990年代以降、生産機能の移転と不動産業への進出を積極的に図 ることで産地としての存立基盤の崩壊を導いた存在でもある。織屋の支配力は産業と地域 社会の両方において強く作用し、西陣の地域社会変動は一般的に見られる新一旧住民の対 立とは異なる構図で進んだ。つまり、織屋層が宅地開発と町家の商業的転用を主導し、そ の結果、西陣織業の下部アクター=零細事業者らや初期の町家再生の担い手らが直接的 ・ 間接的に排除されていくという構図である ${ }^{20)}$ 。その上で、2000年代中盤以降に登場した 投資家や外部資本は現代の「目的地文化」によりふさわしい形に町家の転用を方向づけ、 魅力的な地域イメージを構築してきた。

\section{5. 結論}

個人らによる草の根的な動きとして始まった西陣の町家再生は、組織的な市民運動に発 展する求心力こそなかったものの、工業社会一脱工業化社会の間の接続・調和の問題を抱 えていたインナーエリアに対する魅力的な解決策として、政策と市場を突き動かす潜在力 を持っていた。「町家ブーム」を京都という大都市のインナーエリアにおける地域社会変 動の一形態としてとらえ、その展開と帰結を解明した本稿からは、次の 2 点が明らかに なった。

第一、1990年代以降、西陣地区の町家の多くは、取り壊され住宅地化の波に飲み込まれ るか、あるいは商業的用途に転用されるかという二者選択を強いられてきた。そして後者 の道を用意してきたのが、歴史的景観の保全をめぐる議論に後押しされ、「目的地文化」の 
拡散を導いた「町家ブーム」である。なお、その具体的展開においては、京都ならではの 特殊性、すなわち典型的なインナーエリアとは異なる地域社会の階層構造の複雑性や、国 際観光都市化の下で進む「伝統の消費」[野田 2006] という文脈が色濃く反映されてきた。

第二、町家の商業的転用の増加と居住・生活機能の相対的な縮小という近年の状況は、 これまでの景観政策に新たな課題を突きつけている。京都市による一連の景観政策の展開 が示すのは、制度的規制によって町並夕の外見を管理することは可能であっても、それが 直ちにその中身である文化や暮らしの維持を意味するわけではない、という点だ。京都の 町に息づく文化や暮らしを生み出してきた地場産業の基盤が大きく摇らぐ現在、政策は何 をどこまで「守る」べきか。歴史的景観の保全はこれまで環境保護やまちづくりの枠組み から論じられることが多かつたが、産業構造の転換や地域社会の変容までを視野に入れた 総合的な都市政策としての観点が必要である。

注

1）『工業統計調査』によると、2014年現在、京都市の事業所数は 2,298 、従業者数は 62,501 人、製造品出荷額は 2 兆 1,092 億 4,749 万円に及ぶ。他の政令指定都市と比べると、京都市の製 造業総生産額は大阪市、横浜市に続く 3 位で、事業所数の構成比率では 2 番目、従業者数の構 成比率では 7 番目に高い。

2) 京都府京都市や宇治市、滋賀県大津市に点在する 17 か所の寺社と城郭が「古都京都の文化 財」として世界文化遺産に登録された。

3）『京都観光総合調査』によると、2014年に京都市を訪れた年間観光客数は 5,564 万人、年間 宿泊者数は 1,341 万人 (うち外国人宿泊者数は 183 万人) 、観光消費額は 7,626 億円であった。

4）本稿では、京都市 [2000] による定義に習い、町家を「昭和 25 年以前に伝統軸組構法により 建築された職住一体型の木造家屋」と定義する。その上で、「町家ブーム」を「1990年代以 降、町家が持つ社会的・文化的・経済的価值が多方面から注目され、町家の賃貸・売買価格の 上昇とともに町家を再利用した商業的空間が幅広い人気を集めている現象」とする。

5）京都タワーの建設に触発された 1960 年代の第一次景観論争以降、京都では様々な住民・市民 グループによる景観まちづくり運動が活発に展開されてきた。各地における主な住民運動の展 開については片桐 [2000］、京都での運動については木村 [2007］を参照されたい。

6）ここでは 1960 年代のロンドンにおける都市構造の変動と居住層の入れ替えを説明した初期 のジェントリフィケーション概念 (Glass 1964) を発展させたものとして、1980年代以降、高度 資本主義の発展に伴う都市の景観展開、すなわち湾岸地区の再開発や大都市で林立するホテル とコンベンション会場の複合施設、大規模な高級オフィス・住宅開発、そしてお酒落で高級な

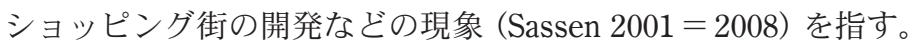

7）「京町家ブームと町家に住むこと」『京都新聞』2005年 5 月 1 日朝刊。

8）Aさん、2016年 6 月 22 日のインタビューより。

9）Cさん、2016年 8 月 3 日のインタビューより。括弧内は筆者による注記である。

10）Bさん、2016年 6 月 29 日のインタビューより。

11）たとえば、1992年に発足したNPO法人「京町家再生研究会」を先駆けに、そこから派生し た形で「京町家作事組」、「京町家友の会」「京町家情報センター」などが次々と結成された。 
12）中林 [2008] によると、新景観政策の特徵は次の 5 点にまとめられる。第一、市内全域にわ たる建物の高さ制限の強化。とりわけ都心部の高さ制限が $31 \mathrm{~m} か ~ 15 \mathrm{~m}$ (幹線道路沿いは $45 \mathrm{~m}$ から $31 \mathrm{~m}$ ) に強化された。第二、大景観・盆地景観を重視する視点の導入。第三、必ずし も伝統的建造物を多く含まない低層高密市街地までを含む景観地区の拡大適用。第四、世界遺 産・名勝地の範囲拡大。第五、美観地区・風致地区における地域独自のデザイン基準の導入。

13）たとえば、長年にかけて景観まちづくりに関わってきた司法専門家の I さんは、制度に明記 された住民協議が実際には十分に機能していないことや、景観地区内でも地区計画などの例外 的な規制緩和の装置が取られることがあると指摘する (2016年 10 月 7 日のインタビューより)。

14）町家の市場価値に関する明確なデータは存在しないが、本稿では次の記事を参照した。「観 光客増で商機拡大 京町家を働く場所、簡易宿所に」(『京都新聞』2016年 9 月 29 日朝刊)、

'Living in Japan's past in traditional townhouses' (The New York Times, 2008. 2.4)

15） Gさん、2016年8月 3 日のインタビューより。

16)『\& TRAVEL京都 2017』2016、朝日新聞出版。

17）ただし、李・吉田 [2013］の調査対象は「京都市上京区の北から中立売通りまで、西から堀 川通りまで」と設定されているため、本稿より狭小な地理的範囲を対象にした分析である。

18） Fさん、2016年 9 月 2 日のインタビューより。括弧内は筆者による注記である。

19）Bさん、2016年 6 月 29 日のインタビューより。

20）たとえば、不動産関係の制度に詳しいCさんは、「昔は町家の立ち退きなどについて相談さ れることが多かった。地上げが盛んだつた時は、追い出される借り手に法的な知識を理解して もらって、出たくなかったら権利を主張するようにアドバイスをしていた。時期としては 1990年代の、町家がどんどん解体していつた頃。（中略）追い出される立場の人々は経済的に あまり余裕がなく、西陣織の関係者が多かった」と振り返っている。

\section{文献リスト}

饗庭 伸・加藤仁美・鈴木伸治・伊達美徳・根上彰生・柳沢 厚ほか編著, 2008, 『初めて学ぶ 都市計画』市ヶ谷出版社.

青山佳孝編, 2002, 『職住共存の都心再生』学芸出版社.

Brumann, C., 2012, Tradition, Democracy and the Townscape of Kyoto: Claiming a Right to the Past, Routledge.

第21次西陣機業調査委員会, 2016, 『西陣機業調査の概要』.

Glass, R., 1964, 1964, London: Aspects of Change, London: Center for Urban studies.

花岡和聖・中谷友樹・矢野桂司・磯田 弦, 2009, 「京都市西陣地区における京町家の建替えの 要因分析」『地理学評論』82(3) : 227-42.

Hareven, T. K., 2002, The Silk Weavers of Kyoto: Family and Work in a Changing Traditional Industry, University of California Press.

藤塚吉浩, 1992 , 「京都市西陣地区におけるジェントリフィケーションの兆候」『人文地理』44 (4) : 57-68.

布施鉄治, 1990, 「東京墨田区における事業体・世帯 (家族) の生産・生活様式変容と地域社会の 構造的変質過程——現下における『家』的社会の構造変質諸過程分析」『調査と社会理論』 研究報告書 $14: 33-76$.

本庄栄治郎, 1930, 『西陣研究』改造社.

片方信也, 2007, 『西陣——織のまち・京町家』つむぎ出版. 
片桐新自, 2000,「歴史的環境へのアプローチ」片桐新自編『歴史的環境の社会学』新曜社, $1-23$.

木原啓吉, 1982, 『歴史的環境一一保存と再生』岩波出版.

木村万平, 2007, 『京都破壊に抗して——市民運動20年の軌跡』かもがわ出版.

国土交通省，2004，『町家等の再生・活用ガイドライン』.

黒松 巌, 1965, 『西陣機業の研究』ミネルヴァ書房.

京都新聞社編, 1995, 『京の町家考』京都新聞社.

京都市, 1993, 『新京都市基本計画』.

京都市, 2000, 『京町家再生プラン—くらし・空間・まち』.

京都市, 2007, 『新景観政策——時を超え光り輝く京都の景観づくり』.

京都市, 2016, 『京都市の工業——平成26年工業統計調査結果報告』.

京都市，2016，『京都観光総合調査』.

李 泰憲・吉田友彦， 2013，「登録簿抽出調査に基く用途混在型小規模製造業密集地域の土地利

用変容に関する考察——西陣織物集積地を事例として」『政策科学』20 (2)：123-34.

松井久美枝， 1979 , 「大都市機業地域西陣の地域構造—その中心と縁辺部における実態調査よ

り」『人文地理』36 (6) : 481-500.

宗田好史, 2009, 『町家再生の論理一一創造的まちづくりへの方途』学芸出版社.

中林 浩, 2008, 「卓越した生活景としての京都の景観」鯵坂 学・小松秀雄編『京都の「まち」 の社会学』世界思想社, 78-97.

野田浩資, 2006,「伝統の消費一一京都市における町家保全と都市再生をめぐって」『環境社会学 研究』 $12: 57-71$.

逢 軍・中村 圭, 2008, 「京町家の社会学」鯵坂 学・小松秀雄編『京都の「まち」の社会学』 世界思想社, 98-120.

Sassen, S., 2001, The Global City: New York, London, Tokyo, Princeton University Press. (=2008, 伊豫谷登士翁監訳『グローバル・シティ—ニューヨーク・ロンドン・東京から世界を読 む』筑摩書房.)

高橋勇悦編，1992，『大都市社会のリストラクチャリング——東京のインナーシティ問題』日本 評論社.

谷口浩司・仏教大学西陣地域研究会編, 1993, 『変容する西陣の暮らしと町』法律文化社.

渡邊喜久, 1997, 「西陣織物業の生産システム—生産工程の分業化と人間主体生産システム」 『東海学園大学研究紀要』 $2: 47-68$.

芳野俊郎，2011，「西陣地域産業と暮らしの持続的発展を求めて」『社会福祉学部論集』，佛教大 学, $7: 109-126$.

Zukin, S., 2010, Naked City, Oxford University Press（=内田奈芳美・真野洋介訳，2013，『都市は なぜ魂を失ったか—ジェイコブズ後のニューヨーク論』講談社.

（きむ そん夕／大妻女子大学社会情報学部非常勤講師・同志社大学創造経済研究センター嘱託 研究員) 